\title{
In vitro ANTIMALARIAL ACTIVITY AND CYTOTOXICITY OF SOME SELECTED CUBAN MEDICINAL PLANTS
}

Aymé Fernández-Calienes VALDÉS(1), Judith Mendiola MARTíNEZ(1), Ramón Scull LIZAMA(2), Yamilet Gutiérrez GAITÉN(2), Deyanira Acuña RODRÍGUEZ(1) \& Juan Abreu PAYROL(2)

\begin{abstract}
SUMMARY
Terrestrial plants have been demonstrated to be sources of antimalarial compounds. In Cuba, little is known about antimalarial potentials of plant species used as medicinals. For that reason, we evaluated the antimalarial activity of 14 plant species used in Cuba as antimalarial, antipyretic and/or antiparasitic. Hydroalcoholic extracts were prepared and tested in vitro for the antimalarial activity against Plasmodium falciparum Ghana strain and over human cell line MRC-5 to determine cytotoxicity. Parasite multiplication was determined microscopically by the direct count of Giemsa stained parasites. A colorimetric assay was used to quantify cytotoxicity. Nine extracts showed $\mathrm{IC}_{50}$ values lower than $100 \mu \mathrm{g} / \mathrm{mL}$ against $P$. falciparum, four extracts were classified as marginally active (SI $<4$ ), one as partially active (Parthenium hysterophorus) exhibiting SI equal to 6.2 and two extracts as active (Bambusa vulgaris and Punica granatum), showing SI $>10$. B. vulgaris showed the most potent and specific antiplasmodial action $\left(\mathrm{IC}_{50}=4.7 \mu \mathrm{g} / \mathrm{mL}, \mathrm{SI}=\right.$ 28.9). Phytochemical characterization of active extracts confirmed the presence of triterpenoids in $B$. vulgaris and polar compounds with phenol free groups and fluorescent metabolites in both extracts as major phytocompounds, by thin layer chromatography. In conclusion, antimalarial use of $B$. vulgaris and $P$. hysterophorus was validated. $B$. vulgaris and $P$. granatum extracts were selected for follow-up because of their strong antimalarial activity.
\end{abstract}

KEYWORDS: Malaria; Ethnopharmacology; Ethnomedicine; Antiparasitic; Antiprotozoal; Toxicity.

\section{INTRODUCTION}

Malaria is one of the major threats concerning world public health. There are around 250 million clinical cases every year and almost one million deaths, mostly children, which are attributable to this disease $\mathrm{s}^{35}$ The main reasons that explain this worsening situation are therapy problems $^{30}$ : resistance to the current antimalarial drugs ${ }^{33}$, unavailability and unaffordability of antimalarial drugs ${ }^{4}$ and lack of new therapeutic targets ${ }^{3}$. These facts have led to searches for new antimalarial compounds.

Plant species have demonstrated their potential to provide effective drugs for the treatment of malaria. Two of the most effective antimalarial drugs available, quinine and artemisinin, are derived from terrestrial plants. For that reason, many research groups screen plant extracts searching for new therapeutic alternatives.

A search of Cuban medicinal species with antimalarial activity is being developed in our laboratory. Products with antimalarial activity have been isolated from plants used against other parasites ${ }^{5,10}$ and some antimalarial natural products have shown good activity against a broad spectrum of parasites ${ }^{1,13}$. So, we included in our investigation, in addition to antimalarials and antipyretics, plant species used in our country as antiparasitic.
Pharmacological evaluation of seven species used in Cuba as antimalarial or antipyretic by the Cuban population was previously developed by our group ${ }^{11,29}$ obtaining low activity or non-specific action against $P$. falciparum. In this study, the activity of 14 medicinal plant species against $P$. falciparum was assayed. Cytotoxicity on human fibroblasts was also evaluated in order to determine the selectivity of antimalarial action.

\section{MATERIALS AND METHODS}

Plant material: Plant species were selected after a revision of the classic Cuban book "Plantas medicinales, venenosas y aromáticas de Cuba", written by Juan Tomás Roig ${ }^{28}$. Identification and collection of the fourteen plant species were made by a botanical specialist (Dr. Ramón Scull) in the Cuban National Botanical Garden, Havana City, in August 2006. Plant specie, vernacular name, part of the plant studied and registration number in the garden are shown in Table 1. Medicinal use of interest (concerning to antimalarial, antipyretic and/ or antiparasitic uses) is shown in Table 2.

Plant parts were carefully collected to avoid contamination with other parts of the plant and strange materials. Vegetal material was dried in a

(1) Departamento de Parasitología. Instituto de Medicina Tropical Pedro Kourí. Autopista Novia del Mediodía Km 61². Marianao 13. La Habana. Cuba.

(2) Departamento de Farmacia. Instituto de Farmacia y Alimentos. Universidad de La Habana. Calle 222. La Coronela. La Habana. Cuba.

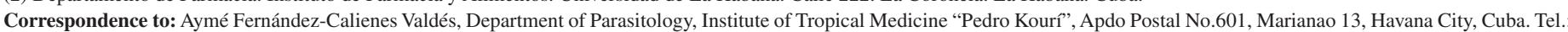
53-7-202 06 50. E-mail: ayme@ipk.sld.cu 
VALDÉS, A.F.C.; MARTÍNEZ, J.M.; LIZAMA, R.S.; GAITÉN, Y.G.; RODRÍGUEZ, D.A. \& PAYROL, J.A. - In vitro antimalarial activity and cytotoxicity of some selected Cuban medicinal plants. Rev. Inst. Med. Trop. Sao Paulo, 52(4): 197-201, 2010.

Table 1

List of medicinal plant species tested for antimalarial activity

\begin{tabular}{|c|c|c|c|}
\hline Specie (Family) & Vernacular name & Part tested & Voucher number \\
\hline Bambusa vulgaris Schrad. Ex J.C. Wendl. (Poaceae) & Caña Brava & Aerial parts & 9500087 \\
\hline Bursera simaruba (L.) Sarg. (Burseraceae) & Almácigo & Aerial parts & 8603305 \\
\hline Cymbopogon citratus (D C.) Stapf. (Poaceae) & Caña santa & Aerial parts & 8700008 \\
\hline Lepidium virginicum L. (Brassicaceae) & Mastuerzo & Aerial parts & 8700259 \\
\hline Luffa aegyptiaca Mill. (Cucurbitaceae) & Estropajo & Aerial parts & 0600366 \\
\hline Manguifera indica L. (Anacardiaceae) & Mango & Aerial parts & 9700175 \\
\hline Melia azedarach L. (Meliaceae) & Paraíso & Bark & 8603268 \\
\hline Ocimun sanctum L. (Lamiaceae) & Albahaca morada & Aerial parts & 9200485 \\
\hline Parthenium hysterophorus L. (Asteraceae) & Escoba amarga & Root & 9700175 \\
\hline Picramnia pentandra Sw. (Simaroubaceae) & Aguedita & Aerial parts & 8603268 \\
\hline Punica granatum L. (Punicaceae) & Granado & Bark & 8300050 \\
\hline Stachytarpheta jamaicensis (L.) Vahl. (Verbenaceae) & Verbena Cimarrona & Aerial parts & 9200475 \\
\hline Tamarindus indica L. (Caesalpiniaceae) & Tamarindo & Bark & 8300068 \\
\hline Turnera ulmifolia L. (Turneraceae) & Marilope & Aerial parts & 8602024 \\
\hline
\end{tabular}

ventilated incubator at $30^{\circ} \mathrm{C}$ and subsequently milled in coarse particles of about $5 \mathrm{~mm}$.

Preparation of extract: One extract for each collected species was prepared. Liquid extraction of the dried processed plant material was achieved by maceration during seven days ${ }^{19}$ in ethanol $80 \%$, using a relation of 1:10 vegetal material mass/solvent volume. The solvent was removed by evaporation at reduced pressure during 24 hours and the remaining residue was frozen at $-70{ }^{\circ} \mathrm{C}$ for 48 hours before lyophilization. Stock solutions of each lyophilized sample were reconstituted in $100 \%$ dimethyl sulphoxide (DMSO) at $40 \mathrm{mg} / \mathrm{mL}$ and stored at $4{ }^{\circ} \mathrm{C}$ until use.

Antiplasmodial activity test: The chloroquine-susceptible $P$. falciparum Ghana strain (GHA) was kindly donated by the Laboratory for Microbiology, Parasitology and Hygiene (LMPH), University of Antwerp, Belgium. Parasites were cultured in human $\mathrm{A}^{+}$erythrocytes at $37{ }^{\circ} \mathrm{C}$ under a low oxygen atmosphere $\left(3 \% \mathrm{O}_{2}, 4 \% \mathrm{CO}_{2}\right.$ and $\left.93 \% \mathrm{~N}_{2}\right)$ in a modular incubator chamber (ICN Biomedicals, USA). The culture medium was RPMI-1640, supplemented with $20 \%$ human serum.

The experiments were performed in 96-well culture plates (Nunc); extracts were tested at two-fold dilutions in a dose-titration range of 100 $\mu \mathrm{g} / \mathrm{mL}$ to $1.56 \mu \mathrm{g} / \mathrm{mL}$. One hundred microliters of infected human red blood cells suspension ( $1 \%$ parasitemia, $4 \%$ hematocrit), with more than $90 \%$ of ring forms, were added to each well containing $100 \mu \mathrm{L}$ of extracts pre-diluted in RPMI-1640. Test plates were incubated for 48 hours. Parasite multiplication was determined microscopically after Giemsa staining and expressed as a percentage of the controls without extract. More than 2000 red blood cells were examined for parasite presence at each concentration per one experiment. The extract concentration showing inhibition of parasite multiplication was tested three times. Concentration of extracts that inhibits $50 \%$ of parasite growth $\left(\mathrm{IC}_{50}\right)$ was calculated by linear interpolation. Chloroquine sulphate (Sigma Chemical
Co.) was used as reference drug.

Cytotoxicity assay: A human diploid embryonic lung cell line MRC5 , was used to assess the cytotoxic effects of plant extracts. Cells were cultivated in Minimum Essential Medium (MEM), supplemented with L-glutamine $(20 \mathrm{mM}), 16.5 \mathrm{mM}$ sodium hydrogen carbonate and 5\% Fetal Calf Serum (FCS) at $37{ }^{\circ} \mathrm{C}$ and $5 \% \mathrm{CO}_{2}$. For the assay, $100 \mu \mathrm{L}$ of cell suspension containing 15,000 cells were seeded onto each well of 96-well plate. After formation of the confluent monolayer, $2 \mu \mathrm{L}$ of stocks pre-diluted in culture medium were added to each well for a final dose range of $500 \mu \mathrm{g} / \mathrm{mL}$ to $1.56 \mu \mathrm{g} / \mathrm{mL}$. Fibroblasts were maintained for 72 hours under $5 \% \mathrm{CO}_{2}$ atmosphere. DMSO $(0.1 \%)$ and untreated cultures were included as controls. The cytotoxicity was determined using the MTT assay ${ }^{20}$. Briefly, after incubation period, $10 \mu \mathrm{L}$ of stock MTT solution $(5 \mathrm{mg} / \mathrm{mL})$ was added to each well and plates were incubated at $37{ }^{\circ} \mathrm{C}$ for four hours. Then, $100 \mu \mathrm{L}$ of sodium dodecyl sulfate solution (SDS $10 \%$ in $0.01 \mathrm{M} \mathrm{HCl}$ ) were added to each well and the amount of formazan formed was measured by scanning it with an ELISA reader at $560 \mathrm{~nm}$ and a background of $630 \mathrm{~nm}$. The percentage of inhibition was calculated. The $50 \%$ cellular cytotoxic concentration $\left(\mathrm{CC}_{50}\right)$ of test extracts was calculated by linear interpolation. The selectivity index (SI) was calculated as the ratio of the $\mathrm{CC}_{50}$ to the $\mathrm{IC}_{50}$.

Criteria of antiplasmodial activity: Extract exhibiting $\mathrm{IC}_{50 \text { P.falciparum }}>$ $100 \mu \mathrm{g} / \mathrm{mL}$ was considered inactive. Extract showing $\mathrm{IC}_{50 \text { P.falciparum }}<100$ $\mu \mathrm{g} / \mathrm{mL}$ was classified as follows: Marginally active at SI $<4$, partially active at SI 4-10 and active at SI $>10$. Active extract showing $\mathrm{IC}_{50 \text { Pfalciparum }}$ $<10 \mu \mathrm{g} / \mathrm{mL}$ should be selected for further bioassay-guided fractionation.

Phytochemical analysis: Samples of the most active extracts were characterized using the main chemical reactions for most significant metabolites ${ }^{17}$ : Dragendorff reaction for alkaloids detection, Fehling for reductor substances, Baljet to detect lactonic compounds, resins test, 
foam test to detect saponins, Lieberman-Burchard for triterpenoids and/ or steroids, $\mathrm{FeCl}_{3}$ for phenols and tanins, ninhidrin to detect aminoacids, Börntrager for quinones, Kedde for cardiotonic glycosides, anthocyanidin test and Shinoda to detect flavonoids.

Thin layer chromatography (TLC) coupled with chemical or physical methods was used for identification of different secondary metabolites. Glass sheets coated with silica gel $60 \mathrm{~F}_{254}(4 \times 5 \mathrm{~cm})$, were used. The chromatography was run in a chamber with ethyl acetate: methanol: water $(10: 1.3: 1, \mathrm{v} / \mathrm{v})$ as the mobile phase. Exposure to ultraviolet (UV) light at 254 and $366 \mathrm{~nm}$, ammonia vapour and vainillin/sulphuric spray followed by heating at $105^{\circ} \mathrm{C}$, were used for the visualization of chromatograms.

\section{RESULTS}

All ethanolic extracts of the 14 species were assayed for antimalarial activity against $P$. falciparum chloroquine-susceptible GHA-strain. The $\mathrm{IC}_{50}$ values, $\mathrm{CC}_{50}$ values and selectivity indices $(\mathrm{SI}=$ ratio of cytotoxicity to antimalarial activity) of extracts are shown in Table 2. Extracts from nine species $\left(64.28 \%\right.$ ) exhibited $\mathrm{IC}_{50}<100 \mu \mathrm{g} / \mathrm{mL}$. Four extracts were classified as marginally active and one as partially active (P. hysterophorus) exhibiting SI of 6.2. Only two extracts were found active, $B$. vulgaris and $P$. granatum, they showed $\mathrm{SI}>10$ and $\mathrm{IC}_{50}<10$ $\mu \mathrm{g} / \mathrm{mL}$. Chloroquine, used as a reference antimalarial drug, tested in parallel had an $\mathrm{IC}_{50}$ of $0.02 \mu \mathrm{M}$.

Phytochemical screening was consistent with the detection of alkaloids, lactones, triterpenoids and/or steroids, phenols, quinones, flavonoids and anthocyanidines in the two extracts, whereas, the presence of saponins and aminoacids were detected only in B. vulgaris. Figure 1 shows that the analyzed extracts were mixtures of compounds: strong spots at the baseline of chromatography (compounds with polar characteristics) were observed for the two extracts, these spots exhibited a yellow color after ammonia exposure confirming the presence of free phenols groups; spots in the solvent front were observed in $B$. vulgaris, treatment with sulphuric acid and vainillin was consistent with

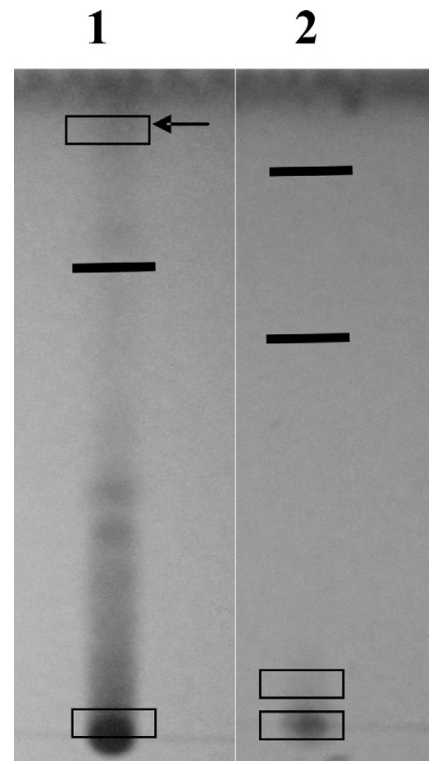

Fig. 1 - Combined profile of spots observed after thin layer chromatography of the B. vulgaris (1) and P. granatum (2) extracts, exposed to UV $254 \mathrm{~nm}$, with spots observed at visible light (open rectangles) and UV $366 \mathrm{~nm}$ (black lines, blue fluorescence). Profile after sulphuric/ vainillin treatment was very similar to the obtained after UV $254 \mathrm{~nm}$ exposure; arrow indicates the red spot position.

Table 2

In vitro antiplasmodial activity and cytotoxicity of plant extracts

\begin{tabular}{|c|c|c|c|c|c|}
\hline Extract & Medicinal use & $\begin{array}{l}\text { P. falciparum } \mathrm{IC}_{50} \\
(\mu \mathrm{g} / \mathrm{mL})\end{array}$ & $\begin{array}{c}\text { MRC-5 CC }{ }_{50} \\
(\mu \mathrm{g} / \mathrm{mL})\end{array}$ & SI & Classification \\
\hline B. vulgaris & Against paludic fevers & 4.7 & 136.7 & 28.9 & $\mathrm{~A}$ \\
\hline B. simaruba & Against intermitent fevers & $>100$ & - & - & I \\
\hline C. citratus & Antipyretic & $>100$ & - & - & I \\
\hline L. virginicum & Antihelminthic & $>100$ & - & - & I \\
\hline L. aegyptiaca & Antihelminthic & 46.5 & 138.1 & 2.9 & MA \\
\hline M. indica & Antipyretic & 64.0 & 20.0 & $<1$ & MA \\
\hline M. azedarach & Antihelminthic & 66.2 & 250.0 & 3.7 & MA \\
\hline O. sanctum & Antipyretic & 40.1 & 63.1 & 1.5 & MA \\
\hline P. hysterophorus & Against paludic fevers & 45.2 & 282.8 & 6.2 & $\mathrm{PA}$ \\
\hline P. pentandra & Quina substitute, against intermitent fevers & 66.5 & 125.2 & 1.8 & MA \\
\hline P. granatum & Antihelminthic & 9.1 & 121.5 & 13.3 & A \\
\hline S. jamaicensis & Antihelminthic, against tertian fevers & 76.0 & 62.0 & $<1$ & MA \\
\hline T. indica & Antipyretic & $>100$ & - & - & I \\
\hline T. ulmifolia & Antipyretic & $>100$ & - & - & I \\
\hline
\end{tabular}

(I) Inactive; (MA) Marginally active; (PA) Partially active; (A) Active 


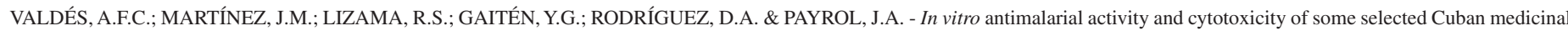
plants. Rev. Inst. Med. Trop. Sao Paulo, 52(4): 197-201, 2010.

triterpenoids (red color); at UV exposure fluorescent spots appear, blue spots were particularly significant at $366 \mathrm{~nm}$.

\section{DISCUSSION}

The remarkable activity of quinine and related drugs and the success of artemisinin have stimulated the search for new plantderived antimalarials. A large number of plants have been screened for antiplasmodial activity ${ }^{15,26}$.

Selection of the plant species to be studied is obviously a crucial step for the ultimate success of the investigation. Three strategies are currently pursued: random collection of plant material, targeted collection based on consideration of chemotaxonomic relationships and the exploitation of ethnomedical information ${ }^{26}$. Identification of new plant-derived antimalarial using an ethnopharmacological approach appears to be more predictive compared with random screening ${ }^{29}$.

In Cuba, malaria was eradicated in 1971 and no recent ethnobotanical data is available. However, Cuban ethnobotanical information has been compiled by several researchers. All species included in this study were selected after revision of the most important Cuban text about medicinal plants $^{28}$. In another way, the selected plants are abundant in the wild and their cultivation is easy with a low cost, which guarantees enough quantities to perform the pharmacological evaluations.

Usually, plant species used as antimalarials and antipyretics, are the targets of antimalarial screening. We included in our study five species used as antipyretic and five which uses are more closely related with an antimalarial action (against paludic fevers, intermitent fevers, tertian and quartan fevers and/or to substitute quina) but we also evaluate four species used as antihelminthic. Last criteria was based on reports about activity of some products derived from plants, including current antimalarial drug artemisinin, against a wide number of parasites ${ }^{1,16}$ and plants used against other parasitic infections which are sources of antimalarial compounds ${ }^{5,10}$.

Multiple efficacy parameters for in vitro antimalarial activity have been proposed ${ }^{4,7,8,21,36}$. For crude extracts, $\mathrm{IC}_{50}$ values should certainly be below $100 \mu \mathrm{g} / \mathrm{mL}^{4,7}$, although most promising antimalarial extracts exhibit $\mathrm{IC}_{50}$ values under $10 \mu \mathrm{g} / \mathrm{mL}^{4,15,31}$. To estimate the potential of molecules or extracts to inhibit parasite growth without toxicity, the selectivity index (SI) was introduced. Low SI indicates that the antiplasmodial activity is probably due to cytotoxicity rather than activity against the parasite themselves. In contrast, high SI should offer the potential of safer therapy ${ }^{31}$. We decided to define 4 as minimal SI value to validate a safe antimalarial use, whereas, SI greater than 10 and $\mathrm{IC}_{50}$ values under $10 \mu \mathrm{g} / \mathrm{mL}$ should be promising sources of antimalarial molecules.

We observed some activity against $P$. falciparum in a high percentage of tested species; the antipyretic group shows the highest percentage of inactive extracts. In the case of malaria, plants may function either by acting directly on the parasite and relieving the symptoms, i.e., fever, or by acting via a specific mechanism ${ }^{4}$. Obviously, in vitro study presumes a direct action on the parasite, and the antipyretic use could be more properly evaluated in vivo.

Although antimalarial activity has been detected in some Poaceae species $^{23,31}$ this is the first report for $B$. vulgaris. Phytochemical analysis of the extract suggests the presence of alkaloids, triterpenoids, flavonoids and lactonic compounds, chemical classes with widely demonstrated effective antimalarial activity ${ }^{4}$.

In Cuba, as in other Latin American countries, $P$. granatum is used as antihelminthic and against intestinal disorders ${ }^{6,27}$. For this specie, amoebicidal $^{6}$, antibacterial ${ }^{17}$, antifungal ${ }^{21}$ and antileishmanial ${ }^{12}$ activities have been reported. Antimalarial action has been studied using fruit rind extracts ${ }^{9,26}$. The activity was associated to the fraction enriched with tannins ${ }^{9}$. Ellagic acid (EA) ${ }^{9}$, gallagic acid $^{26}$, EA glycoside ${ }^{9}$ and ellagitannins ${ }^{9,26}$ were considered to be responsible for activity. The presence of phenolic compounds in our extract was also demonstrated.

Phytochemical screening of our most potent antimalarial extracts revealed a positive reaction for lactonic compounds, whereas, TLC shows blue fluorescence after UV light at $366 \mathrm{~nm}$ exposure, it could suggest the presence of coumarins in both extracts ${ }^{16}$. Coumarins, have been isolated as active principle of plants used as antimalarials in Latin America ${ }^{2,14}$, Africa $^{22}$ and Asian folk medicine ${ }^{34}$.

In conclusion, the antimalarial use of $P$. hysterophorus and B. vulgaris was validated and extracts of $P$. granatum and $B$. vulgaris were selected for further follow-up because of their strong antimalarial activity and the presence of chemical classes with proved efficacy against $P$. falciparum.

\section{RESUMEN}

\section{Actividad antimalárica in vitro y citotoxicidad de algunas plantas medicinales Cubanas seleccionadas}

Las plantas terrestres han demostrado ser fuentes de compuestos antimaláricos. En Cuba, el conocimiento sobre el potencial antimalárico de las plantas medicinales es escaso. Por esta razón, evaluamos la actividad antimalárica de 14 especies de plantas usadas en Cuba como antimaláricas, antipiréticas y/o antiparasitarias. Se prepararon extractos hidroalcohólicos y se probaron in vitro frente a la cepa Ghana de Plasmodium falciparum para la actividad antimalárica y frente a la línea celular humana MRC-5 para determinar citotoxicidad. La multiplicación de los parásitos se determinó microscópicamente mediante el conteo directo de los parásitos teñidos con Giemsa. Un ensayo colorimétrico se utilizó para cuantificar la citotoxicidad. Nueve extractos mostraron valores de CI50 frente a Plasmodium falciparum por debajo de $100 \mu \mathrm{g} /$ $\mathrm{mL}$; cuatro extractos se clasificaron como marginalmente activos (IS < 4), uno parcialmente activo (Parthenium hysterophorus) exhibiendo IS de 6.2 y dos activos (Bambusa vulgaris y Punica granatum) mostrando IS $>10$. B. vulgaris, mostró la acción más potente y específica $\left(\mathrm{CI}_{50}=4,7 \mu \mathrm{g} / \mathrm{mL}\right.$, IS $=28,9)$. La caracterización fitoquímica de los extractos más activos; confirmó la presencia de triterpenoides en $B$. vulgaris y de compuestos polares con grupos fenólicos libres y metabolitos fluorescentes en ambos extractos como fitocompuestos principales mediante cromatografía en capa delgada. En conclusión, se validó el uso antimalárico de $B$. vulgaris y $P$. hysterophorus. Los extractos de B. vulgaris y $P$. granatum se seleccionaron para seguimiento por su potente actividad antimalárica.

\section{REFERENCES}

1. Anthony JP, Fyfe L, Smith H. Plant active components - a resource for antiparasitic agents? Trends Parasitol. 2005;21:462-8 
VALDÉS, A.F.C.; MARTÍNEZ, J.M.; LIZAMA, R.S.; GAITÉN, Y.G.; RODRÍGUEZ, D.A. \& PAYROL, J.A. - In vitro antimalarial activity and cytotoxicity of some selected Cuban medicinal plants. Rev. Inst. Med. Trop. Sao Paulo, 52(4): 197-201, 2010.

2. Argotte-Ramos R, Ramírez-Avila G, Rodríguez-Gutiérrez M del C, Ovilla-Muñoz M, Lanz-Mendoza H, Rodríguez MH, et al. Antimalarial 4-phenylcoumarins from the stem bark of Hintonia latiflora. J Nat Prod. 2006;69:1442-4.

3. Bathurst I, Hentschel C. Medicines for malaria venture: sustaining antimalarial drug development. Trends Parasitol. 2006;22:301-7.

4. Benoit-Vical F. Ethnomedicine in malaria treatment. I Drugs. 2005;8:45-52.

5. Brahmachari G. Neem - an omnipotent plant: a retrospection. Chembiochem. 2004;5:40821.

6. Calzada F, Yépez-Mulia L, Aguilar A. In vitro susceptibility of Entamoeba histolytica and Giardia lamblia to plants used in Mexican traditional medicine for the treatment of gastrointestinal disorders. J Ethnopharmacol. 2006;108:367-70

7. Cos P, Vlietinck AJ, Berghe DV, Maes L. Anti-infective potential of natural products: how to develop a stronger in vitro 'proof-of- concept'. J Ethnopharmacol. 2006;106:290-302

8. Deharo E, Bourdy G, Quenevo C, Muñoz V, Ruiz G, Sauvain M. A search for natural bioactive compounds in Bolivia through a multidisciplinary approach. Part V. Evaluation of the antimalarial activity of plants used by the Tacana Indians. J Ethnopharmacol. 2001;77:91-8.

9. Dell'Agli M, Galli GV, Corbett Y, Taramelli D, Lucantoni L, Habluetzel A, et al. Antiplasmodial activity of Punica granatum L. fruit rind. J Ethnopharmacol. 2009;125:279-85.

10. Derda M, Hadas E, Thiem B. Plant extracts as natural amoebicidal agents. Parasitol Res. 2009;104: 705-8.

11. Fernández-Calienes Valdés A, Mendiola-Martinez J, Scull-Lizama R, Vermeersch M, Cos P, Maes L. In vitro anti-microbial activity of the Cuban medicinal plants Simarouba glauca DC., Melaleuca leucadendron L. and Artemisia absinthium L. Mem Inst Oswaldo Cruz. 2008;103:615-8.

12. García M, Monzote L, Montalvo AM, Scull R. Screening of medicinal plants against Leishmania amazonensis. Pharm Biol. 2010 (accepted).

13. Hay AE, Ioset JR, Ahua KM, Diallo D, Brun R, Hostettmann K. Limonoid orthoacetate and antiprotozoal compounds from the roots of Pseudocedrela kotschyi. J Nat Prod. 2007;70:9-13.

14. Köhler I, Jenett-Siems K, Mockenhaupt FP, Siems K, Jakupovic J, González JC, et al. In vitro antiplasmodial activity of 4-phenylcoumarins from Exostema mexicanum. Planta Med. 2001;67:89-91.

15. Krettli AU. Antimalarial drug discovery: screening of Brazilian medicinal plants and purified compounds. Expert Opin Drug Discov. 2009;4:95-108.

16. Li Y, Wu YL. How Chinese scientists discovered qinghaosu (artemisinin) and developed its derivatives? What are the future perspectives? Med Trop (Mars). 1998;58:9-12.

17. Lock O. Investigación fitoquímica: métodos para el estudio de los productos naturales. Lima: Universidad del Perú; 1988.

18. Mathabe MC, Nikolova RV, Lall N, Nyazema NZ. Antibacterial activities of medicinal plants used for the treatment of diarrhoea in Limpopo Province, South Africa. J Ethnopharmacol. 2006;105:286-93.

19. Ministerio de Salud Pública. Medicamentos de origen vegetal: extractos y tinturas: proceso tecnológico. La Habana: MINSAP; 1991. (Norma Ramal de Salud Pública (NRSP);
311).

20. Mossman T. Rapid colorimetric assay for cellular growth and survival: application to proliferation and cytotoxicity assay. J Immunol Methods. 1983;65:55-63.

21. Muñoz V, Sauvain M, Bourdy G, Arrázola S, Callapa J, Ruiz G, et al. A search for natural bioactive compounds in Bolivia through a multidisciplinary approach. Part III. Evaluation of the antimalarial activity of plants used by Alteños Indians. J Ethnopharmacol. 2000;71:123-31.

22. Navarro V, Villarreal ML, Rojas G, Lozoya X. Antimicrobial evaluation of some plants used in Mexican traditional medicine for the treatment of infectious diseases. J Ethnopharmacol. 1996;53:143-7.

23. Oketch-Rabah HA, Mwangi JW, Lisgarten J, Mberu EK. A new antiplasmodial coumarin from Toddalia asiatica roots. Fitoterapia. 2000;71:636-40.

24. Okokon JE, Ubulom PM, Udokpoh AE. Antiplasmodial activity of Setaria megaphylla. Phytother Res. 2007;21:366-8.

25. Pink R, Hudson A, Mouriès MA, Bendig M. Opportunities and challenges in antiparasitic drug discovery. Nat Rev Drug Discov. 2005;4:727-40.

26. Potterat O, Hamburger M. Drug discovery and development with plant-derived compounds. In: Petersen F, Amstutz R, editors. Natural compounds as drugs, volume I. Basel: Birkhauser Verlag; 2008. p. 46-108. (Progress in Drug Research; v. 65).

27. Reddy MK, Gupta SK, Jacob MR, Khan SI, Ferreira D. Antioxidant, antimalarial and antimicrobial activities of tannin-rich fractions, ellagitannins and phenolic acids from Punica granatum L. Planta Med. 2007;73:461-7.

28. Roig y Mesa JT. Plantas medicinales, aromáticas o venenosas de Cuba. La Habana: Editorial Científico-Técnica; 1974.

29. Rodríguez-Pérez M, Martínez JM, Rivero LR, Álvarez HMH, Valdez AFC, Rodríguez DA, et al. Evaluación de la actividad antimalárica de algunas plantas utilizadas en la medicina tradicional cubana. Rev Cienc Farm Básica Apl. 2006;27:197-205.

30. Saxena S, Pant N, Jain DC, Bhakuni RS. Antimalarial agents from plant sources. Curr Sci. 2003; $85: 1314-29$

31. Soh PN, Benoit-Vical F. Are West African plants a source of future antimalarial drugs? J Ethnopharmacol. 2007;114:130-40.

32. Tchoumbougnang F, Zollo PH, Dagne E, Mekonnen Y. In vivo antimalarial activity of essential oils from Cymbopogon citratus and Ocimum gratissimum on mice infected with Plasmodium berghei. Planta Med. 2005;71:20-3.

33. Trape JF, Pison G, Spiegel A, Enel C, Rogier C. Combating malaria in Africa. Trends Parasitol. 2002;18:224-30.

34. Yang YZ, Ranz A, Pan HZ, Zhang ZN, Lin XB, Meshnick SR. Daphnetin: a novel antimalarial agent with in vitro and in vivo activity. Am J Trop Med Hyg. 1992;46:1520 .

35. World Health Organization. World Malaria Report 2008. Geneva: WHO. [Online]. Available from: http://www.who.int/malaria/publications/atoz/9789241563697/en/ index.html

36. Zihiri GN, Mambu L, Guédé-Guina F, Bodo B, Grellier P. In vitro antiplasmodial activity and cytotoxicity of 33 West African plants used for treatment of malaria. J. Ethnopharmacol. 2005;98:281-5

Received: 19 January 2010

Accepted: 14 June 2010 